\title{
Ready for a world without antibiotics? The Pensières Antibiotic Resistance Call to Action
}

\author{
Jean Carlet ${ }^{1 *}$, Vincent Jarlier ${ }^{2}$, Stephan Harbarth ${ }^{3}$, Andreas Voss ${ }^{4}$, Herman Goossens ${ }^{5}$ and Didier Pittet ${ }^{3}$, for \\ the Participants of the 3rd World Healthcare-Associated Infections Forum ${ }^{6}$
}

\begin{abstract}
Resistance to antibiotics has increased dramatically over the past few years and has now reached a level that places future patients in real danger. Microorganisms such as Escherichia coli and Klebsiella pneumoniae, which are commensals and pathogens for humans and animals, have become increasingly resistant to third-generation cephalosporins. Moreover, in certain countries, they are also resistant to carbapenems and therefore susceptible only to tigecycline and colistin. Resistance is primarily attributed to the production of beta-lactamase genes located on mobile genetic elements, which facilitate their transfer between different species. In some rare cases, Gramnegative rods are resistant to virtually all known antibiotics. The causes are numerous, but the role of the overuse of antibiotics in both humans and animals is essential, as well as the transmission of these bacteria in both the hospital and the community, notably via the food chain, contaminated hands, and between animals and humans. In addition, there are very few new antibiotics in the pipeline, particularly for Gram-negative bacilli. The situation is slightly better for Gram-positive cocci as some potent and novel antibiotics have been made available in recent years. A strong and coordinated international programme is urgently needed. To meet this challenge, 70 internationally recognized experts met for a two-day meeting in June 2011 in Annecy (France) and endorsed a global call to action ("The Pensières Antibiotic Resistance Call to Action"). Bundles of measures that must be implemented simultaneously and worldwide are presented in this document. In particular, antibiotics, which represent a treasure for humanity, must be protected and considered as a special class of drugs.
\end{abstract}

Keywords: antibiotic resistance, antibiotic stewardship, infection control, hand hygiene, surveillance networks, care bundles, environment, regulations, human medicine, animal medicine

\section{Background}

In the golden age of the discovery of antibiotics, these potent "miracle" drugs saved millions of lives. In contrast, we are entering an era where bacterial infections, such as bloodstream infections and ventilator-associated pneumonia, might no longer be successfully treated with antibiotics [1]. We now face a dramatic challenge resulting from two combined problems. First, microorganisms are becoming extremely resistant to existing antibiotics, in particular Gram-negative rods (e.g., Escherichia coli, Salmonella spp, Klebsiella spp, Pseudomonas aeruginosa, Acinetobacter spp), which are resistant to almost all currently available antibiotics in some settings. Resistance

\footnotetext{
* Correspondence: jeancarlet@gmail.com

${ }^{1}$ Consultant, WHO African Partnerships for Patient Safety, 9 rue de la Terrasse, 94000 Créteil, France

Full list of author information is available at the end of the article
}

can be combined with virulence, acting as a potentially deadly duo, as observed in the recent large epidemic outbreak of E. coli 0104:H4 in Europe, notably in Germany [2]. Second, the antibiotic pipeline has become extremely dry [3]. Several new powerful compounds active against Gram-positive cocci have been made available in the last few years, but this is not the case for Gram-negative bacteria and almost no new antibiotic class active against multiresistant Gram-negative rods can be anticipated in the near future. Although hard to imagine, the reality is that many clinicians will soon face a therapeutic dead end in the treatment of certain types of severe bacterial infections. This worrisome situation takes us back to the pre-antibiotic era of the 1930s and early 1940s $[1,3,4]$. We cannot look at this evolving and pandemic threat passively and lose one of the most
Ciomed Central

(C) 2012 Carlet et al; licensee BioMed Central Ltd. This is an Open Access article distributed under the terms of the Creative Commons Attribution License (http://creativecommons.org/licenses/by/2.0), which permits unrestricted use, distribution, and reproduction in any medium, provided the original work is properly cited. 
important drugs discovered in the previous century. We must act now; silence is not an answer.

In this position paper, we summarize important messages and conclusions from the $3^{\text {rd }}$ World HealthcareAssociated Infections (HAI) Forum held in June 2011. The meeting gathered together 70 leading world experts and opinion leaders in the domain of antimicrobial resistance (AMR) from 33 countries to discuss the challenges and possible options to tackle the problem. The main objectives were to structure and propose a hierarchy of the various measures reported in the recent literature and to collect information on the experiences of the many countries represented to discuss if some may be transposable to other nations.

\section{What are the facts about AMR?}

Many alarming facts regarding AMR have accumulated, particularly over the last few years.

- An increase in global resistance rates in many bacterial species responsible for both community- and healthcare-related infections, e.g., staphylococci, enterococci, gonococci, and enterobacteria (including E. coli, Salmonella spp and Shigella spp), Pseudomonas spp, Acinetobacter spp, and Mycobacterium tuberculosis) [1,5-7].

- The burden of bacteremias due to $E$. coli, one of the most common human pathogens, is increasing in Europe, mainly due (but not only) to resistant strains [7].

- Emergence and dissemination of new mechanisms of resistance, e.g., novel extended-spectrum beta-lactamases (ESBL) and carbapenemases [8-12]. The spread of the new resistance gene, the New Delhi metallo-betalactamase 1 (NDM-1), or other carbapenemases in Enterobacteriacae is alarming because these "superbugs" are resistant to most available antibiotics and can disseminate worldwide very rapidly, in particular as a consequence of medical tourism [12].

- The rapid increase in the multiresistance of Gramnegative rods stands in contrast to a steady decrease in methicillin-resistant Staphylococcus aureus (MRSA) rates following the implementation of successful infection control programmes in several high-income countries, such as Belgium, France, United Kingdom (UK), and the USA [13-15]. In some other countries, resistance to both Gram-positive and -negative bacteria is very high (USA for community-acquired (CA)-MRSA; Greece, Italy, Portugal, UK, the USA, and many eastern European and Asian countries for vancomycin-resistant enterococci [VRE]).

- Propensity to use last-line therapy (e.g., carbapenems) to treat healthcare-related and communityacquired infections triggered by a fear of infections caused by ESBL-producing Enterobacteriaceae, despite the fact that these antibiotics should be preserved as our last weapons against multiresistant Gram-negative bacteria.

- Re-use of old drugs with poor safety and efficacy profiles and uncertain pharmacokinetic/pharmacodynamic characteristics (e.g., colistin) due to a lack of alternative drugs [16].

- High morbidity and mortality attributable to multiresistant bacteria in critically ill patients.

- In Europe, the European Centre for Disease Prevention and Control (ECDC) reported that 25,000 people die each year from antibiotic-resistant bacteria [17].

- In the USA, MRSA is associated with a staggering 90,000 infections and an estimated 19,000 deaths annually [18].

\section{- Serious financial consequences of bacterial} resistance.

- Multidrug-resistant organisms (MDROs) result in massive extra healthcare costs and productivity losses of at least 1.5 billion euros each year in Europe [17].

- In the USA, the annual cost of AMR in hospitals is estimated at more than US\$ 20 billion with an even wider clinical impact than human immunodeficiency virus (HIV)-related disease [19].

However, these data on morbidity, mortality, and cost must be considered with caution and may be over- or underestimated because of a lack of in-depth adjustment for risk factors or evaluation of the indirect costs of AMR. Moreover, these figures were calculated before the pandemic with multiresistant Gram-negative rods. Therefore, morbidity, mortality, and the associated economic burden are very likely to increase dramatically during the next decade [20]. Furthermore, with the current European financial crisis resulting in massive cuts in healthcare expenditure and medical research, we can expect multiresistant bacteria to spread more rapidly in hospitals.

\section{What are the causes of this frightening evolution?}

The most important cause is that there has been a massive overuse of antibiotics worldwide across all ecosystems over the past decades, including humans, animals, aquaculture, and agriculture (Additional files $1 \& 2$ ).

When selected silently by antibiotics, a hidden crosstransmission of resistant bacteria occurs daily, both in hospitals and communities. Compliance with hand hygiene practices is far from optimal in many healthcare settings, including hospitals and long-term care facilities [21], thus resulting in a continuous succession of smallsize transmission events difficult to detect, as well as large outbreaks. Exchange of resistant bacteria via travel activities and patient transfers has led to a rapidly 
growing "resistance globalization" as recently exemplified by the spread of NDM-1 [8]. As a consequence, some countries recommend the preemptive isolation of patients admitted from outside their borders based on a suspicion of MDRO carriage in the same philosophy as the "Search and Destroy" programme in The Netherlands [22]. Cross-transmission occurs also in community settings (e.g., schools, families, daycare centres). Finally, hospital and community wastewater systems are an additional source for the dissemination of resistant bacteria.

In particular, the spread of antibiotic-resistant Enterobacteriaceae insensitive to third-generation cephalosporins and carbapenems poses a serious public health threat. Resistance to these beta-lactams is primarily attributed to the production of beta-lactamases, ESBLs and carbapenemases, respectively, and their coding genes located on mobile genetic elements (e.g., plasmids) facilitate intra- and interspecies transfer.

Many countries and healthcare facilities still lack effective antibiotic stewardship programmes [23]. Antibiotics continue to be considered as "ordinary" drugs and are prescribed freely by many different physicians, both in the community and in hospitals. In general, these physicians lack appropriate and rigorous training in infectious diseases and prescribe without any control or help. When national or local programmes do exist, they have often transient effects and require sustained and repeated incentives. As an example, the "Antibiotics are not automatic" ("Les antibiotiques, c'est pas automatique") programme launched in France in the early 2000 s had a very positive effect during five years $(23 \%$ overall decrease in consumption) [24], but consumption is now again on the rise [25]. Self-medication, an important driver of antibiotic overuse, is common, particularly in developing countries where antibiotics can be bought over the counter in pharmacies or in local market places, but it occurs also in Europe, mainly in southern and eastern countries [26]. Antibiotics are used in excess, particularly for common colds and upper respiratory tract syndromes that are mostly of viral origin. Direct sales via the internet are also increasing and difficult to control [27], including sales in some countries of illegal over-the-counter antibiotics and counterfeit drugs that may contain sub-optimal active antibiotic concentrations.

Simultaneously, the antibiotic pipeline is drying up for two reasons (Additional file 3): 1) it is intrinsically difficult to find new antibiotics with novel mechanisms of action; and 2) a high cost/benefit and risk/benefit ratio (length of development, low selling prices, and short treatments) discourage pharmaceutical companies from investment. Moreover, bacteria are rapidly developing when antibiotics are overused, which creates a dilemma for the profit-driven pharmaceutical industry. Therefore, new business models must be developed to encourage research and development arms of companies to engage in the discovery of new antibiotics, but these discussions have turned out to be very difficult. In addition, the financial crisis will probably increase the burden on tax payers and industry to invest in this field.

\section{Is there any national or international reaction to this threat?}

Many national/international meetings, workshops, and task forces, as well as reports in the scientific literature and lay press, have been dedicated to this threat over the last decade, particularly in 2011, but often with a limited impact due to a lack of coordination $[17,18,28-34]$. Only a few developed countries worldwide [13-15,35-37] have managed to reduce antibiotic consumption in the community and/or successfully implemented hand hygiene campaigns in their hospitals, which have sometimes resulted, but not always, in a decrease in resistance. However, despite these efforts, resistance among Gram-negative rods has increased dramatically in parallel, while co-existing with good results for the decrease of MRSA infection [14].

Europe, in particular through the European Union (EU) Directorate General for Health and Consumers (DG SANCO; http://www.ec.europa.edu/dgs/health_consumer/) and the ECDC http://www.ecdc.europa.eu, supports and organizes comprehensive and well-validated surveillance networks for AMR and antibiotic consumption, which has allowed to monitor the impact of these interventions [6,38]. ECDC and the European Medicines Agency (EMA; http://www.ema.europa.eu) have jointly organized a meeting and urged pharmaceutical companies to accelerate the search for new antibiotics [17]. In 2009, a Transatlantic Taskforce for Antimicrobial Resistance (TATFAR; http://ecdc.europa. eu/en/activities/diseaseprogrammes/tatfar/pages/index. aspx?MasterPage $=1$ ) was established during the Swedish EU presidency to promote a mutual understanding of US and European activities and programmes related to AMR issues [39]. A list of 17 recommendations was generated in 2011, but with no incentives on how to reach its stated objectives and no mandate to address the global aspects of this problem http://ecdc.europa. eu/en/activities/diseaseprogrammes/tatfar/documents/ 210911_tatfar_report.pdf.

Regional and international networks or alliances have been developed also with various actions proposed, i.e., Action on Antibiotic Resistance (REACT; http://www. reactgroup.org), Alliance for the Prudent Use of Antibiotics (APUA; http://www.tufts.edu/med/apua/), the European Society for Clinical Microbiology and Infectious Diseases (ESCMID) Study Group on Antibiotic 
Policies (ESGAP; http://www.escmid.org/research_projects/study_groups/esgap/) [40], and the Alliance against MDRO [41]. Finally, in 2011, the World Health Organization (WHO) dedicated the World Health Day to the topic of antimicrobial resistance with the aim to highlight it as a global threat and to call for consolidated efforts to avoid regressing to the pre-antibiotic era http://http//:www.who.int/world-health-day 2011/en/ index.html. Hopefully, this will be the starting point for tangible and sustained efforts by WHO through a worldwide campaign.

\section{Are we ready for a world without antibiotics?}

The answer is clearly no! Today, antibiotics are critical to treat bacterial infections. Indeed, there are very few therapeutic compounds, if any, able to modulate the inflammatory burst during severe sepsis [42]. Anti-toxin therapy could represent a key component of the antibacterial armamentarium of the future, but it is too early to rely on this solution on a routine basis [43]. Antimicrobial peptides are deceiving, particularly when used intravenously [44]. Bacteriophages are tempting, but are not usable by the intravenous route and have not been carefully evaluated so far [45]. Resistance is also an issue with this strategy. Some plants or aromatic substances (e.g., essential oils) may have very interesting antibacterial and antitoxin activities, but again we are far from their use in daily practice [46]. Probiotics have been mentioned as a possible alternative, but could be considered today more as a complement than as a real therapeutic solution. Vaccination is certainly the most promising preventive strategy, but remains limited to a relatively small number of bacteria [47], although there are promising new vaccines entering phase III studies against S. aureus and Clostridium difficile. Without any doubt, antibiotics remain the cornerstone of antibacterial management and they are still acutely needed for the next generations. It is our duty to protect them.

\section{Can we rely on recent positive and transposable programmes?}

The answer is clearly yes, but the examples are few. Education, legislation, and improved diagnosis can reduce antibiotic consumption. Several clinical trials at the community level, have shown that patient education can result in the decrease of the use of antibiotics [48]. The Patients for Patient Safety branch of the WHO Patient Safety Programme has shown that patients can and should have a very active role in making healthcare safer and will be examining how to integrate information on antibiotic resistance within its global training group for 2012 http://www.who.int/patientsafety/patients_for_patient/en/. The EU has established a strategy against AMR to encourage the prudent use of these agents in human medicine. Several countries have launched national campaigns to educate physicians and patients about antimicrobial misuse and the threat of resistance.

The French campaign, often considered as a model, exceeded expectations with a $23 \%$ reduction in the number of antibiotic prescriptions over the first five years [24]. However, nine years after the launch, there are still major concerns about the way in which physicians and patients in France prescribe and consume antibiotics. Despite the sharp reduction of antibiotic prescriptions observed, especially among children, France remains a high user of antibiotics, just behind Greece and Cyprus [6,7].

The Belgian Antibiotic Policy Coordination Committee (BAPCOC) organized several national campaigns, financially supported by the government. These multimedia campaigns, launched in 1999 and targeting the general public, resulted in a $36 \%$ decrease in antibiotic prescription in the community between 1999 and 2007 [35] and decreased antibiotic resistance in Streptococcus pneumoniae and S. pyogenes. The hand hygiene campaigns, launched in 2005 and targeting patients admitted to hospital and healthcare workers, resulted in an increase in hand hygiene compliance and alcohol-based handrub use in hospitals and decreased hospitalacquired (HA)-MRSA.

However, some national campaigns, e.g., Australia, England, Greece, and Spain, have failed to show a major impact on antibiotic prescriptions [35]. In the USA, some very positive results have been obtained for HAMRSA, but not for CA-MRSA, VRE, and ESBL-carrying Enterobacteriaceae [48]. In Israel, some interesting results have been obtained in the use of antibiotics in children [22] and the successful containment of the pandemic with Gram-negative rods [49]. To control selfmedication, the Chilean Ministry of Health has strictly enforced existing laws restricting the purchase of antibiotics without medical prescription since 1999. These regulatory measures have resulted in a $43 \%$ decrease in antimicrobial use in the outpatient setting, which represents a remarkable result [50]. Further interesting results from other countries were highlighted by poster presentations displayed during the meeting and are discussed by Jarlier et al in this issue [51].

Nevertheless, despite targeted information and awareness-raising campaigns, the general public has still preconceived ideas concerning antibiotics and their effects. For example, according to a Pan-European survey published in 2010, 53\% of Europeans still believe that antibiotics kill viruses and $47 \%$ that they are effective against colds and influenza. Large variations between countries were observed and knowledge increased in countries with targeted media campaigns, such as Belgium. Education remains an immense challenge [52]. 


\section{Time for international coordinated actions to save antibiotics}

In response to this global public health threat, 70 leading international experts formulated "The Pensières Antibiotic Resistance Call to Action" during a two-day meeting held in Annecy (France) in June 2011. Lectures were given on a wide range of topics with extensive and in-depth discussion. Each participant presented data and the results of country-specific intervention programmes targeted at the control of AMR and healthcare-associated infection, such as infection prevention and control and antibiotic stewardship strategies. Thirty-four posters provided for the first time a unique overview of actions and policies in place worldwide in 29 countries with an evaluation of their degree of efficacy. At the end of the meeting, participants were asked to rank a series of 25 actions linked to the topics highlighted using a multi-voting system [51].

A coordinated programme based on six main lines of action was defined as follows: 1) a worldwide upgrade in infection control practices to limit resistant bacteria cross-transmission; 2) a worldwide antibiotic stewardship strategy to decrease antibiotic pressure on bacteria; 3) the improved use of diagnostic techniques; 4) an acceleration in the discovery and development of new antibiotics, particularly targeting Gram-negative bacteria; $5)$ the acceleration of vaccine development programmes, and 6) a strong educational programme for both healthcare practitioners, consumers, and children.

The programme is conceived as a "bundle" whose different components should be implemented simultaneously. Implementing only one line of action or selecting only some components will very likely lead to failure. Such a multifaceted programme looks easy to implement, but is in fact a serious challenge. Although the multiple actors to involve have different backgrounds and interests, such as the hospital, community, and human and animal medicine, and may not work spontaneously together, cooperation between all is the key to success.

A strong political commitment at international, national, and local levels is of paramount importance to trigger such an ambitious programme. This is absolutely essential. Recent national or international programmes should be evaluated. Healthcare professionals will need the strong involvement of policy makers through to hospital managers to ensure its adoption. It will take many years to obtain significant results and we will certainly never return to the pre-antibiotic era where all pathogens were fully susceptible to antibiotics. But we have no choice and must preserve antibiotics for the next generations. We must realize also that such a programme is not aiming at simply saving money-and could even increase healthcare costs initially-but it will become eventually cost-effective when taking a longrange perspective.

\section{Effective infection control programmes must be implemented worldwide}

The importance of a coordinated programme combining infection control with other actions in a rational and sustainable manner, e.g., antibiotic stewardship, must be strongly emphasized. Prevention of cross-transmission and epidemics must be based on a multifaceted strategy that should include appropriate screening policies, use of universal precautions, improved hand hygiene, particularly through the systematic recourse to alcohol-based handrub formulations (ABHRs), and specific contact precautions when appropriate (i.e., geographic isolation measures and cohorting). However, several of these measures remain controversial and costly. For instance, it remains unknown if specific isolation precautions are better than standard precautions if the latter are strictly and permanently applied, which so far is hard to obtain [53]. Rapid diagnostic methods are needed more than ever to detect patients colonized by MDROs and the Innovative Medicines Initiative (IMI; http://www.imieuropa.edu) is investing 15 million euros in the RAPPID project (Development of Rapid Point-of-Care Test Platforms for Infectious Diseases; http://www.rapp-id.eu) to develop new diagnostic tools for bloodstream infections, lower respiratory tract infections, and tuberculosis. It is to be hoped that some promising ongoing EUfunded projects will help to find new solutions, e.g., "Mastering hOSpital Antimicrobial Resistance" (MOSAR; http://www.Mosar-sic.org); "Impact of Specific Antibiotic Therapies on the prevalence of hUman host ResistaNt bacteria" (SATURN; http://www.saturn-project.edu); and "Resistance in Gram-Negative Organisms: Studying Intervention Strategies" (R-GNOSIS; http:// www.r-gnosis.eu).

Successful measures for controlling MRSA are probably not sufficient to prevent the spread of ESBL or carbapenemases for several reasons: far higher bacterial load in the gut for Gram-negative rods; fecal excretion; dissemination through waste; transferable resistance genes on plasmid or transposons; lack of effective decolonization regimens; or the substantial role of antibiotic selection pressure by commonly misused drugs. Although MRSA bloodstream infections are decreasing in many European countries, infections due to ESBLproducing Gram-negative rods are increasing in these same countries. To succeed in combating these Gramnegative rods, there is a need to upgrade and tailor the prevention of cross-transmission outside hospitals (e.g., in nursing homes, families, daycare centres, and schools) and to take into account environmental aspects. Moreover, those actors with an important role to play, such 
as specialists in infection control and healthcare managers, have been somewhat paralyzed in front of the ESBL invasion, although sometimes simultaneously very active against MRSA or VRE.

The WHO Global Patient Safety Challenge "Clean Care is Safer Care" is a striking example of a programme that could provide guidance, boost hand hygiene promotion initiatives worldwide, including in developing countries. Proof of effectiveness of additional actions will hopefully be provided by ongoing studies [21]. Quality indicators are needed to assess the performance of hand hygiene procedures in hospitals, e.g., surrogate markers such as the volume of ABHR consumption (used in France, Belgium, and Germany) or, even better, the compliance rate with procedures (e. g., in Australia) as proposed by the WHO strategy [54]. Population migration and health tourism are unavoidable components of the modern era. Hospitals accepting international patients must follow excellent infection control practices and antibiotic stewardship policies in practice and not just on paper, including qualified and trained infection control teams and a hospital management willing to accept their recommendations.

\section{Active protection of antibiotics (part of the so-called "antibiotic stewardship")}

Antibiotics are natural gifts belonging to humanity and strategies for their active protection must be developed in a philosophy of "sustainable development" [1]. A worldwide implementation of antibiotic stewardship programmes is of paramount importance $[23,55]$. This should be based on a multidisciplinary approach aimed at the optimal selection, dosage, and duration of antimicrobial treatment resulting in the best clinical outcome for treatment or prevention of infection with minimal toxicity to the patient, and minimal impact on subsequent resistance. The reason for the prescription and the planned duration of therapy (as well as diagnosis whenever possible) should be indicated on every patient chart. Indeed, in some countries, including the EU, many hospital physicians prescribe antibiotics without mentioning the reason in the patient notes [56]. Finally, some antibiotics should probably be reserved exclusively for human usage. However, there is no consensus with the veterinary world on this measure.

A concerted international programme should induce a marked decrease in the overall consumption of antibiotics in every sector of human and animal medicine, aquaculture, and agriculture. There is no specific culprit and all antibiotic prescribers must work together. A strong and sustained cooperation between healthcare professionals and consumers (antibiotic users) in an ecological and civic attitude is pivotal for the success of these programmes. Antibiotics must be considered as a specific class of drugs [40,57], a central concept that will have many consequences in terms of legislation, particularly at the European level. A major breakthrough would be obtained if antibiotics could be included in the United Nations Educational, Scientific and Cultural Organization (UNESCO) global heritage list for humanity to demonstrate and raise awareness of their long-term importance for human health http://www.whc.unesco. org. Finally, it is of paramount importance to realize that in many countries there is a very limited access to antibiotics, which impairs safety of care. A balance between appropriate usage and access to antibiotics is needed. These two actions are not mutually exclusive, but complementary.

\section{Diagnosis of bacterial infection and antibiotic resistance must be more rapid}

Rapid diagnostic tests should be urgently developed to help physicians to target the organisms causing the infection. Physicians should not rely only on fever, which is very often due to non-bacterial infections, to prescribe antibiotics. Unfortunately, microbiology diagnostic techniques have not evolved much since Pasteur and others were able to grow bacteria at the end of the $19^{\text {th }}$ century, and many of their culture methods are still used today in our routine clinical diagnostic laboratories.

New rapid diagnostic tools, such as point-of-care testing or biomarkers, should be used more widely. These are already available for several microorganisms, including $C$. difficile and MRSA. Simple tests are available to detect Streptococcus pyogenes in the throat, but often not used by general practitioners (5 to $15 \%$ in adults; $30 \%$ in children [58]. Urinary sticks are sensitive enough to avoid treating most patients with a suspicion of urinary tract infection, particularly in long-term care facilities. Procalcitonin can help to differentiate viral and bacterial bronchitis [59].

The development of new tools should be encouraged to help clinicians not to treat patients with antibiotics when bacterial infection is ruled out or, conversely, to help them to prescribe the right antibiotic through rapid identification of the bacteria involved and its antibiotic susceptibility. Re-evaluation of therapy at days two or three should be systematic in all types of practice. Appropriate biomarkers [60] and therapeutic algorithms that include de-escalation strategies will help to reduce the length of therapy and optimize the choice of drugs [61]. After a long period where antibiotic therapy has been mostly empiric in many countries, including the USA, it is time to teach and treat infectious diseases based on diagnostic evidence. This will represent a dramatic change in our paradigm of care and a real challenge. 
New antibiotics are urgently needed and must be efficiently protected

WHO, TATFAR, the Infectious Diseases Society of America (IDSA), and European institutions, as well as healthcare professionals, have proposed measures and incentives to fix the broken antibiotic pipeline and encourage biotechnology and pharmaceutical companies to invest in the development of new antibacterial agents, particularly against Gram-negative bacteria. In 2010, IDSA launched a new initiative entitled " $10 \times 20$ " to mobilize key leaders, research institutions, and scientific associations to create an antibacterial research and development enterprise powerful enough to produce 10 new antibiotics by the year 2020 http://www.idsociety. org/10x20/[62]. Fast-track designation for the development of new drugs (similar to orphan drugs) to help get them earlier to the patient, high prices for antibiotics with a high value compared to others, including active protection and follow-up, are actions that will help to develop new drugs and protect them when marketed. Prolongation of antibiotic patents has been proposed, but remains controversial [63]. The IMI and the European Federation of Pharmaceutical Industries and Associations (EFPIA; http://www.efpia.org) are currently discussing mechanisms to jointly develop new antibiotics.

A strong educational programme must be made available worldwide for both healthcare professionals and consumers

It is of paramount importance that both professionals and consumers understand that the two main causes of antibiotic resistance are their overuse in both humans, animals, and agriculture. A complicity between these two groups is key to the success of such a programme. We need also to provide information to children and to promote and establish large programmes such as the Pan-European e-Bug project http://www.e-bug-edu $[64,65]$. In turn, these children will teach their parents and other family members and will become more clever consumers of healthcare than we have ever been.

\section{Conclusion}

We have overused and abused antibiotics in both humans and animals with huge variations between countries [66]. Today, we have regular and precise barometers to survey resistance levels and antibiotic consumption [67]. Resistance of bacteria to antibiotics has reached levels that place the human race in real danger. Immediate, vigorous, and coordinated measures must be taken worldwide to save and protect the erosion of existing antibiotics and facilitate the appearance of new and potent antibiotics, active in particular against Gramnegative bacilli $[68,69]$. This will need a profound change in the way we diagnose and treat infectious diseases [70]. Dramatic change will be needed also in the way we behave in hospitals and in the community concerning both antibiotic therapy and infection prevention and control measures [71]. Educational programmes targeting both healthcare professionals and consumers, including children, are urgently needed. A strong cooperation and complicity between healthcare providers, including researchers and consumers, is the real key to success.

\section{Additional file 1}

\section{Antibiotic use, misuse, and abuse}

Half of all antibiotic consumption may be unnecessary and greatly contributes to increasing bacterial resistance [28]. In Europe (29 countries), the overall human consumption of antimicrobials was 3350 tons in 2007 [29]. Outpatient consumption varies widely from 11 defined daily doses (DDD) per 1000 inhabitants in The Netherlands to 34 DDD per 1000 inhabitants in Cyprus [38]. In the USA, 3300 tons of antibiotics were sold [18].

\section{Antibiotics are ineffective against viral infections}

- But they are often prescribed for self-limiting illnesses, such as colds and influenza, caused by viruses that will not respond to antibacterial drugs. - Diagnostic uncertainty is a key driver of drug misuse and overuse. Since classical laboratory methods, based on culture of the pathogenic agent, require 36-48 hours to provide results, few infections are accurately diagnosed.

- In the absence of a clear diagnosis, physicians often prescribe antibiotics just "to be on the safe side" or to prevent possible secondary bacterial infections.

- In addition, patients often put pressure on physicians. In a survey conducted in the USA, nearly half (48\%) of respondents indicated that they expected an antibiotic when they visit a doctor [72] In another survey, more than $50 \%$ of French interviewees expected an antibiotic for the treatment of influenza-like illness [73].

\section{It is often falsely assumed that inappropriate use of antibiotics cannot harm}

- According to the US Centers for Disease Control and Prevention (CDC), an estimated 150,000 cases per year present to US emergency departments for antimicrobial-related adverse events [74].

- Incorrect use of antibiotics accelerates AMR. In this respect, AMR is like pollution: it has so little immediately perceptible effect that in the absence of regulation, nothing changes [75]. 
Patient compliance with recommended treatment is another major problem

- Patients forget to take medication or may be unable to afford a full course. They tend to consider antibiotics as antipyretics that treat symptoms and stop taking them as soon as they feel better.

Self-medication is also an important driver of antimicrobial overuse

- It has been observed in the USA [76] and Europe $[77,78]$, particularly for self-limiting illnesses mostly caused by viruses.

- It is especially prevalent in developing countries where antibiotics can be bought over the counter in pharmacies or even in the local market place.

- Sales via the internet drive self-medication; they are on the rise and difficult to control [27].

\section{Additional file 2}

\section{Antibiotic use in animals: a major concern for public} health and the environment

Resistance to antibiotics is increasing both in commensal and pathogenic bacteria, raising an emerging threat to public health and the environment. Antimicrobial administration to food animals is among the most important factors contributing to the selection of antimicrobial-resistant bacteria that can be transmitted from animals to humans. More than half of all antibiotics produced globally are used in animals [29]. In the USA alone, animal agriculture consumes $80 \%$ of all antibiotics used [79]. According to a first-ever estimate of the Food and Drug Administration (FDA), the amount of antibiotics sold for use in food animals in the USA was over 13,000 tons (29 million pounds) in 2009 [80]. The overall national sales of veterinary antimicrobials in 10 European countries was approximately 3500 tons of active substance in 2007 [29]. In 2009, French sales of veterinary antimicrobials were 1067 tons [81].

\section{Antimicrobial use and animal husbandry}

Antimicrobials are used by veterinary practitioners for the treatment and control of infectious diseases in a wide variety of farm and companion animal species. Antibiotic treatment of sick animals is common practice. When a certain percentage of farm animals or certain species (e.g., flocks of broiler chickens or salmon pens) are affected, the entire group is treated, including animals that are not infected. Sub-therapeutic levels of antibiotics are also administered to animals for the prevention of bacterial infections to compensate poor production practices, often without prescription.
Low levels of antibiotic agents are frequently added to animal feed for growth promotion in livestock (mostly in the production of pigs, broiler chickens, turkeys, and feedlot cattle) [82]. This is particularly problematic because antibiotic growth promoters are used without veterinary prescriptions or administered for long periods of time at sub-therapeutic concentrations to entire groups or herds of animals. This favours the selection and spread of resistant bacteria [83].

\section{National legislation}

On January 1 2006, the EU banned the feeding of all antibiotics and related drugs to livestock for growth promotion purposes [84]. The USA has not yet implemented similar control policies for antibiotic use in animal agriculture. However, a recently issued FDA Guidance to Industry called for the use of antibiotics in food-producing animals only when needed to ensure animal health, including phasing in veterinary oversight and consultation, and has attracted growing support within Congress for new legislation $[85,86]$.

\section{Transmission of resistant bacteria from animals to humans}

Widespread use of antimicrobials for disease control and growth promotion in animals has been paralleled by an increase in resistance in those bacteria in animals. Resistant bacteria then spread among groups of animals, including fish, or to the local environment (adjacent soil, air, and water) through the spreading of manure.

- Through long-term survival and transfer of resistant genes to the resident flora [87] Studies carried out in The Netherlands have shown that the proportion of resistant bacteria containing antibiotic resistance genes in the soil has significantly increased since 1940 [88].

- Through direct contact between farm animals and humans (e.g., farmers, farm visitors) The same strains of MRSA have been found in livestock and livestock workers in The Netherlands, Italy, Canada and the USA [89-91].

\section{- Through contaminated food}

Although correct cooking kills bacteria, contamination can occur through improper handling before cooking. Many of the antimicrobial-resistant E. coli strains that cause urinary tract and bloodstream infections in humans appear likely to have been acquired from contaminated retail meat.

In The Netherlands, $94 \%$ of a representative sample of chicken retail meat was contaminated with ESBL-producing E. coli isolates, of which $39 \%$ were also found in human clinical samples tested in 31 microbiological laboratories [92,93]. An association between the approval of fluoroquinolones for use in food-producing animals and the development of fluoroquinolone- 
resistant Salmonella and Campylobacter in animals and humans has been observed in several countries [31,94-96]. Reports of the spread of multidrug resistant Salmonella Schwarzengrund from chickens to humans in Thailand and from imported Thai food products to humans in Denmark and the USA [97].

\section{Use of antibiotics in food animals may result in the deposition of residues in animal products and the environment}

- Consumption of antibiotic residues represents a potential threat to human health, through direct toxicity, allergic reactions, or alteration of the bacterial flora present in the human digestive tract [98].

- To safeguard humans from exposure to antibioticadded food, a withholding period must be observed until the residues are no longer detected before the animal or animal products can be processed. Heavy responsibility is placed on the veterinarian and livestock producer to observe the period of withdrawal. In Europe, rapid tests are regularly performed to check the absence of antibiotic residues in food.

- Eliminating the unnecessary usage of antibiotics implies a change in mindset, integrating both long-term public health concerns and productivity. This involves everyone - from governments to producers to the consumer. To stem the rising threat of resistant bacteria to human health, there is an urgent need for regulation of antibiotic usage in animals at the global level.

\section{Additional file 3}

\section{The antibiotic pipeline is running dry}

In the past, the discovery of potent new classes of antimicrobials allowed to provide therapeutic options for newly emerging AMR. During the 30 years following the introduction of penicillin, scientists discovered a wide range of antimicrobials to treat bacterial diseases. By the early 1970s, 11 distinct antibiotic classes and more than 270 antibiotics had been brought into clinical use [99].

The process of novel antimicrobial discovery has slowed to a virtual standstill. Most antimicrobials introduced since the early 1970s have been chemical modifications of previously discovered classes of drugs [40]. The promise of genomics in discovering new antibiotic entities has remained largely unfulfilled to date.

\section{Pharmaceutical companies have curtailed their anti-} infective research programmes

- Of the 15 companies with previous had antibiotic discovery programmes, only 5 still maintain an active research and development capacity in antibiotics [32].

- According to two recent reports from IDSA [33] and the ECDC and EMEA [17], there are only a few candidates in company pipelines.
- Only 15 antibiotics under development (mostly in the early phases) present a new mechanism of action with the potential to meet the challenge of multidrug resistance. Of these, only two, both in the early development phase, may be active against multidrug- resistant Gram-negative bacteria, a group of bacteria causing serious therapeutic concerns due to their increasingly high resistance to antibiotics.

\section{Why is the antibiotic pipeline drying up?}

The discovery and development of new antimicrobials is an expensive and time-consuming process. Pharmaceutical companies must prioritize competing projects and antibiotic development has a lower priority than other competing drugs in the portfolio.

- In the late 1960s, infectious diseases were thought to be conquered, opening the way for a shift in resources to chronic conditions, such as cancer and cardiovascular diseases.

- The limited duration of antibiotic treatments makes them less profitable than other drugs prescribed for years to treat chronic conditions, such as hypertension and diabetes.

- There is strong competition with other drugs already on the market. While resistance is an emerging problem, low-priced generic antibiotics on the market are still effective in treating most infections and are used as first-line therapy.

- New antibiotics may be kept as last-resort treatments, resulting in low sales for companies.

- New antimicrobials can also have a limited lifespan because of the development of resistance.

- Modifications in regulatory procedures have been perceived as having created an "unfriendly" environment. Regulators have been demanding demonstrations of the relative efficacy of new antibiotics versus those already registered within tighter statistical parameters, i. e., shifting from "non-inferiority" to "superiority" trials $[40,100]$.

\section{Additional material}

Additional file 1: Antibiotic use, misuse, and abuse. Supplementary list of the main issues discussed (references [72-78]).

Additional file 2: Antibiotic use in animals: a major concern for public health and the environment. Supplementary list of the main issues discussed (references [79-98]).

Additional file 3: The antibiotic pipeline is running dry

Supplementary list of the main issues discussed (references $[99,100]$ ).

\section{List of abbreviations}

ABHRs: alcohol-based handrubs; AMR: antimicrobial resistance; APUA:

Alliance for the Prudent Use of Antibiotics; BABCOC: Belgian Antibiotic Policy Coordination Committee; CA-MRSA: community-acquired methicillin-resistant 
Staphylococcus aureus; CDC: Centers for Disease Prevention and Control; DDD: defined daily dose; DG-SANCO: Directorate General for Health and Consumers; ECDC: European Centre for Disease Prevention and Control; EFPIA: European Federation of Pharmaceutical Industries and Associations; EMEA: European Medicines Agency; ESGAP: European Society for Clinical Microbiology and Infectious Diseases (ESCMID) Study Group on Antibiotic Policies; EU: European Union; ESBL: extended-spectrum beta-lactamase; FDA: Food and Drug Administration; HA-MRSA: hospital-acquired methicillinresistant Staphylococcus aureus; HIV: human immunodeficiency virus; IDSA: Infectious Diseases Society of America; IMI: Innovative Medicines Initiative; MDROs: multidrug-resistant organisms; MOSAR: Mastering; hOSpital: Antimicrobial Resistance; MRSA: methicillin-resistant Staphylococcus aureus; NDM-1: New Delhi metallo-beta-lactamase 1; RAPP-ID: Development of Rapid Point-of-Care Test Platforms for Infectious Diseases; REACT: Action on Antibiotic Resistance; R-GNOSIS: Resistance in Gram-Negative Organisms: Studying Intervention Strategies; SATURN: Impact of Specific Antibiotic Therapies on the prevalence of hUman host ResistaNt bacteria; TATFAR: Transatlantic Taskforce for Antimicrobial Resistance; UK: United Kingdom; UNESCO: United Nations Educational, Scientific and Cultural Organization; USA: United States of America; VRE: vancomycin-resistant enterococci; WHO World Health Organization

\section{Acknowledgements}

We thank Isabelle Caniaux for her excellent support and organization of the meeting and Marie-Françoise Gros for her help in focusing the messages contained in the call for action. We thank Rosemary Sudan for editing this document with patience and professionalism.

Source of funding

bioMérieux organized the $3^{\text {rd }}$ World Forum on Healthcare-Associated Infections and funded the participation of attendees. The funding body had no role in the collection and interpretation of data presented, including the writing of the manuscript, and in the decision to submit the manuscript for publication.

List of participants to the $3^{\text {rd }}$ World Forum on Healthcare-Associated Infections, Annecy, France, 27-29 June 2011

ABDUL GHAFUR Kulakkattil, Chennai, India; ALLEGRANZI Benedetta, Geneva, Switzerland; AWANG JALIL Nordiah, Kuala Lumpur, Malaysia; BALKHY Hanan, Riyadh, Saudi Arabia; BAVESTRELLO Luis, Viña del Mar, Chile; CANTON Rafael, Madrid, Spain; CARLET Jean, Créteil, France; CARMELI Yehuda, Tel Aviv, Israel; COIGNARD Bruno, Saint Maurice, France; CONA Erna, Santiago de Chile, Chile; CONLY John, Calgary, Canada; COOKSON Barry, London, UK; CORSO Alejandra, Buenos Aires, Argentina; CREMIEUX Anne Claude, Garches, France; CYRILLO Marcos Antonio, Sao Paulo, Brazil; DURLACH Ricardo Augusto, Buenos Aires, Argentina; DUSE Adriano, Houghton, South Africa; FANNING Seamus, Dublin, Ireland; GASTMEIER Petra, Berlin, Germany; GOLDMANN Donald, Boston, USA; GOOSSENS Herman, Antwerp, Belgium; GOTTLIEB Thomas, Woollahra, Australia; GRAYSON Lindsay, Melbourne, Australia; GUZMAN BLANCO Manuel, Caracas, Venezuela; HARBARTH Stephan, Geneva, Switzerland; HAUSTEIN Thomas, Geneva, Switzerland; HERWALDT Loreen, Iowa, USA; HOLLIS Aidan, Calgary, Canada; HOLMES Alison, London, UK; HOSOGLU Salih, Diyarbakir, Turkey; HRYNIEWICZ Waleria, Warsaw, Poland; HU Bijie, Shanghai, China; JAGGI Namita, Gurgaon-Haryana, India; JARLIER Vincent, Paris, France; JARVIS William, Port Orford, USA; KAKU Mitsuo, Sendai, Japan; KIM Eui-Chong, Seoul, Korea; KLUGMAN Keith, Atlanta, USA; KLUYTMANS Jan, Breda, The Netherlands; LING Moi Lin, Singapore; MARTINEZ-MARTINEZ Luis, Santander, Spain; McGOWAN John, Atlanta, USA; MEHTAR Shaheen, Cape Town, South Africa; MORO Maria Luisa, Bologna, Italy; NATHWANI Dilip, Dundee, UK; NDOYE Babacar, Dakar, Senegal; NICOLLE Lindsay, Winnipeg, Canada; NORDMANN Patrice, Le-Kremlin-Bicetre, France; PATERSON David, Bulimba, Australia; PERENCEVICH Eli, lowa City, USA; PERL Trish, Baltimore, USA; PITTET Didier, Geneva, Switzerland; RICHTMANN Rosanna, São Paulo, Brazil; ROSSI Flavia, São Paulo, Brazil; RYAN John, European Commission, Luxembourg; SAMORE Mattew, Utah, USA; SETO Wing Hong, Hong Kong, SAR, China; SIFUENTES OSORNIO José, Mexico City, Mexico; SKOV Robert, Copenhagen, Denmark; SOMOGYI PEREZ Teresa, San José, Costa Rica; SRINIVASAN Arjun, Atlanta, USA; TACCONELLI Evelina, Rome, Italy; TSAKRIS Athanassios, Athens, Greece; UPHAM Garance, Prevessin, France; VALLEJO Martha, Medellin, Columbia; VAN BELKUM Alex, La Balme Les Grottes, France; VANDENBROUCKE-GRAULS Christina, Amsterdam, The Netherlands; VANHEMS Philippe, Lyon, France; VOSS Andreas, Nijmegen, The Netherlands; WALSH Timothy, Cardiff, UK.

\section{Author details}

${ }^{1}$ Consultant, WHO African Partnerships for Patient Safety, 9 rue de la Terrasse, 94000 Créteil, France. ${ }^{2}$ UPMC University Paris 6 EA, 154 Laboratory of Bacteriology-Hygiene and Microbiology, Hôpital Pitié-Salpétrière, Assistance Publique des Hôpitaux de Paris, 47-83 Boulevard de l'Hôpital, 75013 Paris, France. Infection Control Programme and WHO Collaborating Centre on Patient Safety, University of Geneva Hospitals and Faculty of Medicine, 4 Rue Gabrielle-Perret-Gentil, 1211 Geneva 14, Switzerland. ${ }^{4}$ Canisius-Wilhelmina Ziekenhuis and Radboud University Medical Centre, NTPDRD189, Postbus 9015, 6500 GS, Nijmegen, The Netherlands. 'Laboratory of Medical Microbiology, University Hospital Antwerp, Wilrijkstraat 10, 2650 Edegem, Belgium. ${ }^{6} 3^{\text {rd }}$ World Forum on Healthcare-Associated Infections, Annecy, France, 27-29 June 2011.

\section{Authors' contributions}

$J C$ conceived and drafted the manuscript and produced the different versions, in particular the reference list. VJ and DP provided an extensive review of the first draft of the manuscript. DP, SH, HG, and AV reviewed the manuscript and provided important intellectual content. All attendees to the meeting were given the possibility to comment on the content. All authors have read and approved the final version of the manuscript. Disclaimer

The content of this paper expresses the views of the experts co-authoring it and in no way represents the position of their affiliations.

\section{Competing interests}

Jean Carlet has served as a consultant for Biomerieux, Astra-Zeneca, Astellas, Thermo-Fisher, Da Voltera, and Aromatechnologies. John Conly has received honoraria from the Canadian Agency for Drugs and Technologies in Health for work as an expert reviewer and clinical expert, respectively, for projects on the role of rapid polymerase chain reaction (PCR) testing for MRSA in hospitalized patients, and the use of vancomycin or metronidazole for the treatment of $C$. difficile colitis. He has also received speaker's honoraria related to new antibacterial agents from Janssen-Ortho, Pfizer, and Astellas Pharma during the past five years. All other authors declare no competing interests.

Received: 18 January 2012 Accepted: 14 February 2012 Published: 14 February 2012

\section{References}

1. Carlet J, Collignon P, Goldmann D, Goosens H, Gyssens IC, Harbarth S, Jarlier V, Levy SB, N'Doye B, Pittet D, Richtmann R, Seto WH, van der Meer JW, Voss A: Society's failure to protect a precious resource: antibiotics. Lancet 2011, 378:369-371.

2. Buchholz U, Bernard H, Werber D, Böhmer MM, Remschmidt C, Wilking H, Deleré $Y$, van der Heiden M, Adlhoch C, Dreesman J, Ehlers J, Ethelberg S, Faber M, Frank C, Fricke G, Greiner M, Höhle M, Ivarsson S, Jark U, Kirchner M, Koch J, Krause G, Luber P, Rosner B, Stark K, Kühne M: German outbreak of Escherichia coli 0104:H4 associated with sprouts. N Engl J Med 2011, 365:1763-1770.

3. Hughes JM: Preserving the lifesaving power of antimicrobial agents. JAMA 2011, 305:1027-1028.

4. Piddock $L$ : The crisis of no new antibiotics-what is the way forward? Lancet Infect Dis 2011.

5. Carlet J, Mainardi JL: Antibacterial agents: back to the future. Can we live with only colistin, co-trimoxazole, and fosfomycin. Clin Microbiol Infect 2012.

6. European Centre for Disease Prevention and Control: EARS-Net database. [http://edc.europa.eu].

7. Gagliotti C, Balode A, Baquero F, Degener J, Grundmann H, Gür D, Jarlier V, Kahlmeter G, Jarlier V, Kahlmeter G, Monen J, Monnet DL, Rossollini GM, Suetens C, Weist K, Heuer O, EARS-Net Participants (Disease Specific Contact Points for AMR): Escherichia coli and Staphylococcus aureus: bad news and good news from the European Antimicrobial Resistance Surveillance Network (EARS-Net, formely EARSS), 2002 to 2009. Euro Surveill 2011, 16, pii:19819.

8. Meir S, Weber R, Zbinden R, Ruef C, Hasse B: Extended- spectrum betalactamases-producing Gram negative pathogens in community-acquired urinary tract infections: an increasing challenge for antimicrobial therapy. Infection 2011. 
9. Hawser SP, Bouchillon SK, Lascols C, Hackel M, Hoban DJ, Badal R, Canton R: Susceptibility of European Escherichia coli clinical isolates from intra-abdominal infections, extended-spectrum beta-lactamases occurrence, resistance distribution, and molecular characterization of ertapenem-resistant isolates (SMART 2008-2009). Clin Microbiol Infect 2011.

10. Gupta N, Limbago BM, Patel JB, Kallen AJ: Carbapenem-resistant enterobacteriaceae: epidemiology and prevention. Clin Infect Dis 2011 53:60-67.

11. Naas T, Cozon G, Gaillot O, Courcol R, Nordmann P: When carbapenemhydrolizing ss-lactamase KPC meets Escherichia coli ST-131 in France. Antimicrob Agents Chemother 2011.

12. Kumarasamy KK, Toleman MA, Walsh TR: Emergence of a new antibiotic resistance mechanism in India, Pakistan, and the UK: a molecular, biological, and epidemiological study. Lancet Infect Dis 2010, 10:597-602.

13. Van Gastel E, Costers M, Peetermans WE, Struelens MJ, Hospital Medicine Working Group of the Belgian Antibiotic Policy Coordination Committee: Nationwide implementation of antibiotic management teams in Belgian hospitals: a self-reporting survey. J Antimicrob Chemother 2010, 65:576-580.

14. Wilson J, Elgohari S, Livermore DM, Cookson B, Johnson A, Lamagni T, Chronias A, Sheridan E: Trends among pathogens reported as causing bacteraemia in England, 2004-2008. Clin Microbiol Infect 2011, 17:451-458.

15. Jarlier V, Trystram D, Brun-Buisson C, Fournier S, Carbonne A, Marty L, Andremont A, Arlete G, Buu-Hoi A, Carlet J, Decré D, Gottot S, Gutmann L, Joly-Guillou ML, Legrand P, Nicolas-Chanoine MH, Soussy CJ, Wolf M, Lucet JC, Aggoune M, Brücker G, Régnier B, Collégiale de BactériologieVirologie-Hygiène des Hôpitaux Universitaires de I'lle de France: Curbing methicillin Staphylococcus aureus in 38 French hospitals through a 15year institutional program. Arch Intern Med 2010, 170:552-559.

16. Couet W, Gregoire N, Marchand SH, Momoz O: Colistin pharmacokinetics: the fog is lifting. Clin Microbiol Infect 2012.

17. ECDC/EMEA Joint Technical Report: The bacterial challenge: time to react. 2009, EMEA/576176/2009. http://www.ema.europa.eu/docs/en_GB/ document_library/Report/2009/11/WC500008770.pdf.

18. Alliance for the Prudent Use of Antibiotics: The cost of antibiotic resistance to US families and the health care system. [http://www.tufts. edu/med/apua/news/press_release_7-13-10.shtml], http://www.tufts.edu/ med/apua/consumers/personal_home_5_1451036133.pdf.

19. Roberts R, Hota B, Ahmad I, Scott RD, Foster SD, Abbasi F, Schabowski S, Kampe LM, Ciavarella GG, Supino M, Naples J, Cordell R, Levy SB, Weinstein RA: Hospital and societal costs of antimicrobial-resistant infections in a Chicago teaching hospital: implications for antibiotic stewardship. Clin Infect Dis 2009, 49:1175-1184.

20. De Kracker MEA, Davey PG, Grundmann H, on behalf of the BURDEN group: Mortality and hospital stay associated with resistant Staphylococcus aureus and Escherichia coli bacteremia: estimating the burden of antibiotic resistance in Europe. PLOS Med 2011, 8:e1001104.

21. Allegranzi B, Storr J, Dziekan G, Leotsakos A, Donaldson L, Pittet D: The first global patient safety challenge "Clean care is safer care": from launch to current progress and achievements. J Hosp Infect 2007, 65(Suppl 2):115-123.

22. Swaber MJ, Lev B, Israeli A, Solter E, Smollan G, Rubinovitch B, Shalit I, Carmeli Y, Israel Carbapenem-Resistant Enterobacteriaceae Working Group: Containment of a country-wide outbreak of carbapenem-resistant Klebsiella pneumonia in Israeli hospitals via a nationally implemented intervention. Clin Infect Dis 2011, 52:848-855.

23. Dellit TH, Owens RC, MCGowan JE, Gerding DN, Weinstein RA, Burke JP, Huskins WC, Paterson DL, Fishman NO, Carpenter CF, Brennan PJ, Billeter M, Hooton TM, Infectious Diseases Society of America; Society for Healthcare Epidemiology of America: Infectious Diseases Society of America and the Society for Healthcare Epidemiology of America guidelines for developing an institutional program to enhance antimicrobial stewardship. Clin Infect Dis 2007, 44:159-157.

24. Sabuncu E, David J, Bemede-Bauduin C, Pépin S, Leroy M, Boëlle PX, Watier L, Guillemot D: Significant reduction of antibiotic use in the community after a nationwide campaign in France, 2002-2007. PLoS Med 2009, 6:e1000008.

25. Agence française de sécurité sanitaire des produits de santé: Dix ans d'évolution des consommations d'antibiotiques en France. 2011 [http:// www.afssaps.fr/var/afssaps_site/storage/original/application/ 263354f238b8f7061cdb52319655ca07.pdf].

26. Campos J, Ferech M, Lazaro E, de Abajo F, Oteo J, Stephens P, Goossens H: Surveillance of outpatient antibiotic consumption in Spain according to sales data and reimbursement data. J Antimicrob Chemother 2007, 60:698-701.

27. Mainous AG, Everett CJ, Post RE, Diaz VA, Hueston WJ: Availability of antibiotics for purchase without a prescription on the internet. Ann Fam Med 2009, 7:431-435.

28. World Health Organization: Department of Communicable Disease Surveillance and Response: WHO Global Strategy for Containment of Antimicrobial Resistance. WHO/CDS/DRS/2001 1.2 [http://www.who.int/csr/ resources/publications/drugresist/en/EGlobal_Strat.pdf].

29. European Centre for Disease Prevention and Control (ECDC), European Food Safety Authority (EFSA), European Medicines Agency (EMEA) and the European Commission's Scientific Committee on Emerging and Newly Identified Health Risks (SCENIHR): Joint Opinion on antimicrobial resistance (AMR) focused on zoonotic infections. EFSA J 2009, 7:1372 [http://www.efsa.europa.eu/it/efsajournal/doc/1372.pdf].

30. Mossialos E, Morel C, Edwards S, Berenson J, Gemmill-Toyama M, Brogan D: Policies and incentives for promoting innovation in antibiotic research. The London School of Economics and Political Science 2009 [http:/wwwz.lse. ac.uk/LSEHealthAndSocialCare/impacts/Antibiotics\%20Report.aspx].

31. European Food Safety Authority (EFSA): The Community Summary Report on antimicrobial resistance in zoonotic and indicator bacteria from animals and food in the European Union in 2008. EFSA J 2010, 8:1658 [http://www.efsa.europa.eu/en/efsajournal/pub/1658.htm].

32. Infectious Diseases Society of America: Bad bugs, no drugs. 2004 [http:// www.idsociety.org/uploadedFiles/IDSA/Policy_and_Advocacy/ Current_Topics_and_Issues/Antimicrobial_Resistance/10×20/Images/Bad\% 20Bugs\%20no\%20Drugs.pdf\#search=\%22bad\%20bugs\%22].

33. Boucher HW, Talbot GH, Bradley JS, Edwards JE, Gilbert D, Rice LB, Scheld M, Spellberg B, Bartlett J: Bad bugs, no drugs: No ESKAPE! An update from the Infectious Diseases Society of America. Clin Infect Dis 2009, 48:1-12.

34. Acar JF, Davies JE, (co-chairs): Antibiotic resistance: an ecological perspective on an old problem. A report from the American Academy of Microbiology 2009 [http://academy.asm.org/images/stories/documents/ antibioticresistance.pdf].

35. Huttner B, Goossens H, Verheij T, Harbarth S, CHAMP Consortium: Characteristics and outcomes of public campaigns aimed at improving the use of antibiotics in outpatients in high-income countries. Lancet Infect Dis 2010, 10:17-31.

36. Huttner B, Harbarth S: "Antibiotics are not automatic anymore" - The French national campaign to cut antibiotic overuse. PLoS Med 2009, 6: e1000080

37. Carlet J, Astagneau P, Brun-Buisson C, Coignard B, Salomon V, Tran B, Desenclos JC, Jarlier V, Schlemmer B, Parneix P, Regnier B, Fabry J, French National Program for Prevention of Healthcare-Associated Infections and Antimicrobial Resistance: French national program for prevention of health-care-associated infections and antimicrobial resistance.1992-2008: positive trends but perseverance needed. Infect Control Hosp Infect 2009, 30:737-745.

38. European Surveillance of Antibiotic Consumption (ESAC). [http://www. esac.ua.ac.be].

39. ECDC welcomes EU/US transatlantic taskforce on antibiotic resistance. November 2009 and September 2011. [http://www.ecdc.europa.eu/en/ press/news/Lists/News/ECDC_DispForm.aspx?List=32e43ee8-e230-4424a783-85742124029a\&ID=320], http://ecdc.europa.eu/en/activities/ diseaseprogrammes/tatfar/documents/210911_tatfar_report.pdf.

40. Powers JH: Increasing the efficiency of clinical trials of antimicrobials: the scientific basis of substantial evidence of effectiveness of drugs. Clin Infect Dis 2007, 45(Suppl 2):S135-S162.

41. Carlet J, the World Alliance Against Multiple-Resistant Bacteria: Halte à la résistance: sauvons les antibiotiques. Med Mal Inf 2011, 41:351-352.

42. Hotchkiss RS, Opal S: Immunotherapy for sepsis- a new approach against an ancient foe. $N$ Engl J Med 2010, 363:87-89.

43. Neugenauer EA: To use or not to use? Polyclonal intravenous immunoglobulins for the treatment of sepsis and septic shock. Crit Care Med 2007, 35:2855-2858. 
44. Eckert R: Road to clinical efficacy: challenges and novel strategies for antimicrobial peptide development. Future Microbiol 2011, 6:635-651.

45. Hanion GW: Bacteriophages: an appraisal of their role in the treatment of bacterial infections. Int J Antimicrob Agents 2007, 30:118-128.

46. Burt S: Essential oils: their antibacterial properties and potential applications in foods. A review. Int J Food Microbiol 2004, 94:223-253.

47. Spellberg B, Daum R: Development of a vaccine against Staphylococcus aureus. Semin Immunopathol 2011.

48. Finkelstein JA, Huang SS, Kleinman K, Rifas-Shiman SL, Stille CJ, Daniel J, Schiff N, Steingard R, Soumerai SB, Ross-Degnan D, Goldmann D, Platt R: Impact of a 16-community trial to promote judicious antibiotic use in Massachusetts. Pediatrics 2008, 121:e15-23.

49. Regev-Yochay G, Raz M, Dagan R, Roizin H, Morag B, Hetman S, Ringel S, Ben-Israel N, Varon M, Somekh E, Rubinstein E: Reduction in antibiotic use following a cluster randomized controlled multifaceted intervention: the Israeli judicious antibiotic prescription study. Clin Infect Dis 2011, 53:33-41.

50. Bavestrello L, Cabello A, Casanova D: Impact of regulatory measures in the trends of community consumption of antibiotics in Chile. Rev Med Chil 2002, 130:1265-1272.

51. Jarlier V, Carlet J, McGowan J, Goossens H, Voss A, Harbarth S, Pittet D, the participants of the 3rd World Health-care Associated Infections Forum: Priority actions to fight antibiotic resistance: results of an international meeting. ARIC 2012, 1, xxxxx.

52. Read RC, Cornaglia G, Kahlmeter G, European Society of Clinical Microbiology and Infectious Diseases Professional Affairs Workshop Group: Professional challenges and opportunities in clinical microbiology and infectious diseases in Europe. Lancet Infect Dis 2011, 11:408-415.

53. Huskins WC, Huckabee CM, O'Grady NP, Murray P, Kopetskie H, Zimmer L, Walker ME, Sinkowitz-Cochran RL, Jernigan JA, Samore M, Wallace D, Goldmann DA, STAR* ICU Trial Investigators: Intervention to reduce transmission of resistant bacteria in intensive care. N Engl J Med 2011 364:1407-1418

54. Longtin Y, Sax H, Allegranzi B, Schneider F, Pittet D: Videos in clinical medicine. Hand hygiene. N Engl J Med 2011, 364:e 24

55. Antimicrobial stewardship for the community hospital: practical tools and techniques for implementation. Clin Infect Dis 2011, 53(Suppl 1): S1-S30.

56. Zarb J, Amadeo B, Muller A, Drapier N, Vankerckhoven V, Davey $\mathrm{P}$, Goossens H, ESAC-3 Hospital Care Subproject Group: Identification of targets for quality improvement in antibiotic prescribing: the web-based ESAC Point Prevalence Study 2009. Antimicrob Chemother 2010, 65:443-449.

57. Alliance for the Prudent Use of Antibiotics: Antibiotics should be assigned to a special drug class to preserve their power. Press release, 30 July 2010. [http://www.tufts.edu/med/apua/news/press_release_7-13-10. shtml].

58. Madurell J, Balaqué $\mathrm{M}$, Gomez $\mathrm{M}$, Cots JM, Llor C: Impact of rapid antigen detection testing on antibiotic prescription in acute pharyngitis in adults. FARINGOCAT STUDY: a multicentric randomized controlled trial. BMC Fam Pract 2010, 11:25-29.

59. Burkhardt O, Ewig S, Giesdorf S, Giersdorf S, Harmann O, Wegscheider K, Hummers-Pradier $\mathrm{E}$, Welte T: Procalcotonin guidance and reduction of antibiotic use in acute respiratory tract infection. Eur Respir J 2010, 36:601-607.

60. Schuetz P, Albrich W, Christ-Crain M, Chastre J, Mueller B: Procalcitonin for guidance of antibiotic therapy. Expert Rev Anti Infec Ther 2010, 8:575-587.

61. Bouadma L, Luyt CE, Tubach F, Cracco C, Alvarez A, Schwebel C, Schortgen F, Lasocki S, Veber B, Dehoux M, Bernard M, Pasquet B, Régnier B, Brun-Buisson C, Chastre J, Wolff M, PRORATA trial group: Use of procalcitonin to reduce patient's exposure to antibiotics in intensive care units (PRORATA trial): a multicentre randomized controlled trial. Lancet 2010, 375:463-474

62. Infectious Diseases Society of America: The $10 \times$ ' 20 initiative: pursuing a global commitment to develop 10 new antibacterial drugs by 2020. Clin Infect Dis 2010, 50:1081-1083.

63. Outterson K, Samora JB, Keller-Cuda K: Will longer antimicrobial patents improve public health? Lancet Infect Dis 2007, 7:559-566

64. Lecky DM, McNulty CA, Adriaenssens N, Koprivová Herotová T, Holt J, Touboul P, Merakou K, Koncan R, Olczak-Pienkowska A, Avô AB, Campos J, Farrell D, Kostkova P, Weinberg J, e-Bug Working Group: What are school children in Europe being taught about hygiene and antibiotic use? $J$ Antimicrob Chemother 2011, 66(Suppl 5):v13-21.

65. De Quincey E, Kostkova P, Jawaheer G, Farrell D, McNulty CA, Weiberg J, eBug Working Group: Evaluating the on-line activity of users of the e-Bug website. J Antimicrob Chemother 2011, 66(Suppl 5):v45-49.

66. Grave K, Torren-Edo J, Mackay D: Comparison of the sales of veterinary antibacterial agents between 10 European countries. J Antimicrob Chemother 2010, 65:2037-2040.

67. European Commission: Antimicrobial resistance. Eurobarometer 338/ Wave 72.5 - TNS Opinion \& Social. Luxembourg 2010 [http://ec.europa.eu/ health/antimicrobial_resistance/docs/ebs_338_en.pdf].

68. Freire-Moran L, Aronsson B, Manz C, Gyssens IC, Monnet D, Cars O, ECDCEMA Working Group: Critical shortage of new antibiotics in development against multidrug-resistant bacteria - time to react is now. Drug Resist Updat 2011, 14:118-124.

69. Bush K, Courvalin P, Dantas G, Davies J, Eisenstein B, Huovinen P Jacoby GA, Kishony R, Kreiswirth BN, Kutter E, Lerner SA, Levy S, Lewis K, Lomovskaya O, Miller JH, Mobashery S, Piddock L, Projan S, Thomas CM, Tomasz A, Tulkens PM, Walsh TR, Watson JD, Witkowski J, Witte W, Wright G, Yeh P, Zgurskaya HI: Tackling antibiotic resistance. Nat Rev Microbiol 2011, 9:894-898

70. Okeke IN, Peeling RW, Goossens H, Auckenthaler R, Olmsted SS, de Lavison JF, Zimmer BL, Perkins MD, Nordqvist K: Diagnostics as essential tools for containing antibiotic resistance. Drug Resist Updat 2011, 14:95-106

71. Hulscher ME, Grol RP, van der Meer JW: Antibiotic prescribing in hospitals: a social and behavioural scientific approach. Lancet Infect Dis 2010, 10:167-175.

72. Vanden Eng J, Marcus R, Hadler JL, Imhoff B, Vugia DJ, Cieslak PR, Zell E, Deneen V, McCombs KG, Zansky SM, Hawkins MA, Besser RE: Consumer attitudes and use of antibiotics. Emerg Infect Dis 2003, 9:1128-1135.

73. Harbarth S, Albrich W, Brun-Buisson C: Outpatient antibiotic use and prevalence of antibiotic-resistant pneumococci in France and Germany: a sociocultural perspective. Emerg Infect Dis 2002, 8:1460-1467.

74. Powers JH: Antimicrobial drug development - the past, the present, the future. Clin Microbiol Infect 2004, 10(Suppl 4):23-31.

75. The McDonnell Norms Group: Antibiotic overuse: the influence of social norms. J Am Coll Surg 2008, 207:265-275.

76. Richman PB, Garra G, Eskin B, Nashed AH, Cody R: Oral antibiotic use without consulting a physician: a survey of ED patients. Am J Emerg Med 2001, 19:57-60.

77. Grigoryan L, Burgerhof JG, Degener JE, Deschepper R, Lundborg CS, Monnet DL, Scicluna EA, Birkin J, Haaijer-Ruskamp FM, Self-Medication with Antibiotics and Resistance (SAR) Consortium: Determinants of selfmedication with antibiotics in Europe: the impact of beliefs, country wealth and the healthcare system. J Antimicrob Chemother 2008, 61:1172-1179.

78. Väänänen $M H$, Pietilä K, Airaksinen M: Self-medication with antibioticsdoes it really happen in Europe? Health Policy 2006, 77:166-171.

79. Bottemiller H: Most US antibiotics go to animal agriculture. Food Safety News 2011 [http://www.foodsafetynews.com/2011/02/fda-confirms-80percent-of-antibiotics-used-in-animal-ag/] .

80. United States Food and Drug Administration: 2009 Summary report on antimicrobials sold or distributed for use in food-producing animals. [http://www.fda.gov/downloads/Forlndustry/UserFees/ AnimalDrugUserFeeActADUFA/UCM231851.pdf].

81. Chevance A, Moulin G: Suivi des ventes de médicaments vétérinaires contenant des antibiotiques en France en 2009. Anses-Agence nationale du médicament vétérinaire (ANMV) 2011 [http://www.destinationsante.com/ IMG/pdf/110302-rapport-ANMV.pdf].

82. Alliance for the Prudent Use of Antibiotics (APUA): Situation analysis of antibiotic misuse in US food animals: APUA background paper. APUA Newsletter 2010, 28:1-7.

83. Alliance for the Prudent Use of Antibiotics (APUA): Consequences of antibiotic misuse in food animals and interventions: APUA background paper. APUA Newsletter 2010, 28:7-13.

84. European Food Safety Authority (EFSA): Antimicrobial resistance. Consultation 6 March 2011.[http://www.efsa.europa.eu/en/biohaztopics/ topic/amr.htm].

85. The Infectious Diseases Society of America: The Infectious Diseases Society of America's (IDSA) Statement on antibiotic resistance: promoting 
judicious use of medically important antibiotics in animal agriculture before the House Committee on Energy and Commerce Subcommittee on Health. 2010 [http://www.idsociety.org/uploadedFiles/LDA/

Policy_and_Advocacy/Current_Topics_and_Issues/

Advancing_Product_Research_and_Development/Vaccines/Statements/ Testimony\%20n\%20Judicious\%20Use\%20of\%20Antibiotics\%20in\% 20Animals\%20House\%20EC\%20Subcommittee\%20on\%20Health\%20071410, pdf].

86. United States Department of Health and Human Services Food and Drug Administration: Center for Veterinary Medicine: The judicious use of medically important antimicrobial drugs in food-producing animals. Draft guidance \#209 2010 [http://www.fda.gov/downloads/AnimalVeterinary/ GuidanceComplianceEnforcement/GuidanceforIndustry/UCM216936.pdf].

87. Cassone M, Giordano A: Resistance genes travelling the microbial internet: down the drain, up the food chain? Expert Rev Anti Infect Ther 2009, 7:637-639

88. Knapp CW, Dolfing J, Ehlert PA, Graham DW: Evidence of increasing antibiotic resistance gene abundance in archived soils since 1940 . Environ Sci Technol 2010, 44:580-587.

89. Van Loo I, Huijsdens X, Tiemersma E, de Neeling A, van de SandeBruinsma N, Beaujean D, Voss A, Kluytmans J: Emergence of methicillin resistant Staphylococcus aureus of animal origin in humans. Emerg Infect Dis 2007, 13:1834-1839.

90. Smith TC, Male MJ, Harper AL: Methicillin-resistant Staphylococcus aureus (MRSA) strain ST398 is present in Midwestern US swine and swine workers. PLoS One 2009, 4:e4258.

91. Soavi L, Stellini R, Signorini L, Antonini B, Pedroni P, Zanetti L, Milanesi B, Pantosti A, Matteelli A, Pan A, Carosi G: Methicillin-resistant Staphylococcus aureus ST398, Italy. Emerg Infect Dis 2010, 16:346-348.

92. Overdevest I, Willemsen I, Rijnsburger M, Eustace A, Xu L, Hawkey P, Heck M, Savelkoul P, Vandenbroucke-Grauls C, van der Zwaluw K, Huijsdens X, Kluytmans J: Extended-spectrum beta-lactamases genes of Escherichia coli in chicken meat and humans, The Netherlands. Emerg Infect Dis 2011, 17:1216-1222.

93. Graveland H, Wagenaar JA, Heesterbeek $H$, Mevius D, van Duijkeren E, Heederik D: Methicillin-resistant Staphylococcus aureus ST398 in veal calf farming: human MRSA carriage related with animal antimicrobial usage and farm hygiene. PLoS One 2010, 8:e10990.

94. $1^{\text {st }}$ Joint FAO/OIE/WHO Expert Workshop on Non-Human Antimicrobial Usage and Antimicrobial Resistance. Scientific Assessment, Geneva 2003, 4 [http://www.who.int/foodsafety/micro/meetings/nov2003/en/].

95. World Health Organization: Drug-resistant Salmonella. Fact sheet no.139 revised April 2005.[http://www.who.int/mediacentre/factsheets/fs139/en/].

96. Gupta A, Nelson JM, Barrett TJ, et al: Antimicrobial resistance among Campylobacter strains, United States, 1997-2001. Emerg Infect Dis 2004, 10:1102-1109.

97. Aarestrup FM, Hendriksen RS, Lockett J, Gay K, Teates K, McDermott PF, White DG, Hasman H, Sorensen G, Bangtrakulnonth A, Pornreongwong S, Pulsrikarn C, Angulo FJ, Gerner-Smidt P: International spread of multidrugresistant Salmonella Schwarzengrund in food products. Emerg Infect Dis 2007, 13:726-731.

98. Nisha AR: Antibiotic residues - a global health hazard. Vet World 2008, 1:375-377.

99. Power E: Impact of antibiotic restrictions: the pharmaceutical perspective. Clin Microbiol Infect 2006, 12(Suppl 5):25-34.

100. Powers JH: Recommendations for improving the design, conduct and analysis of clinical trials in hospital acquired pneumonia and ventilatorassociated pneumonia. Clin Infect Dis 2010, 51(Suppl 1):S18-S28.

doi:10.1186/2047-2994-1-11

Cite this article as: Carlet et al:: Ready for a world without antibiotics?

The Pensières Antibiotic Resistance Call to Action. Antimicrobial

Resistance and Infection Control 2012 1:11.

\section{Submit your next manuscript to BioMed Central and take full advantage of:}

- Convenient online submission

- Thorough peer review

- No space constraints or color figure charges

- Immediate publication on acceptance

- Inclusion in PubMed, CAS, Scopus and Google Scholar

- Research which is freely available for redistribution

Submit your manuscript at www.biomedcentral.com/submit 